\title{
The influence of cork oak pruning on the yield and growth of cork
}

\author{
Isabel Cañellas* and Gregorio Montero \\ Silviculture Department, CIFOR-INIA, Apdo. 8.111, 28080 Madrid, Spain
}

(Received 8 February 2001; accepted 22 April 2002)

\begin{abstract}
Bearing in mind the importance of pruning as a silvicultural treatment in cork oak (Quercus suber L.) open woodland of the dehesa type, an experiment was designed to assess the effect of pruning on cork yield. This work was carried out in two ways: synchronically, comparing pruned sites with others which were either unpruned or pruned at different times, and diachronically, comparing pruned and unpruned trees within the same site. The five test sites (with forty trees in the synchronic and eighty in the diachronic plots) were selected in south-west Spain. In all cases measurements of the cork production were made in kilos per square metre of surface stripped, total cork yield per tree, and the mean thickness of stripped cork. Analysis was carried out using a paired data comparison test. The effect of pruning on yearly cork growth was also analysed by examining the annual growth rings. In the five plots analysed there were no significant differences ( $95 \%$ confidence intervals) between pruned and unpruned trees in terms of kilos of cork produced per square metre of surface stripped, nor for total cork yield per tree. Neither were there significant differences in annual cork growth rings, even when the pruning was carried out during the cork-stripping period.
\end{abstract}

Quercus suber / pruning / cork production / pruned biomass / cork growth

Résumé - Influence de l'élagage du chêne-liège sur la croissance et la production de liège. Étant donné l'importance de l'élagage comme traitement sylvicole habituel dans les pâturages de chêne liège (Quercus suber $\mathrm{L}$.) du type dehesa, une expérience a été réalisée pour déterminer l'effet de l'élagage sur la production de liège. Ce travail a été mené en suivant deux démarches : d'une part (étude synchronique) en comparant des placettes élaguées et non élaguées, ou bien élaguées à différents moments, et d'autre part (étude diachronique) en comparant dans la même placette des arbres élagués et non élagués. Les cinq placettes d'essai ( 40 arbres dans les placettes synchroniques et 80 arbres dans les diachroniques) ont été choisies dans le sud-ouest de l'Espagne. Dans tous les cas, les kilogrammes de liège produits par mètre carré de surface décortiquée, la production totale de liège par arbre et l'épaisseur moyenne du liège récoltée ont été mesurés. L'analyse statistique a été réalisée avec un test de comparaison de données couplées. L'effet de l'élagage sur la croissance annuelle du liège a été aussi analysé en étudiant les cernes de croissance. Dans les cinq placettes analysées, aucune différence statistiquement significative (95\% d'écart de confiance) n'a été observée entre les arbres élagués et les non élagués pour les kilogrammes de liège produits par mètre carré de surface décortiquée, ni pour la production totale par arbre. Aucune différence n'a pas non plus été trouvée entre les cernes de croissance du liège, même quand l'élagage a été réalisé pendant la période de décorticage.

Quercus suber / élagage / production de liège / biomasse / croissance du liège

\section{INTRODUCTION}

The pruning of cork oaks, as carried out in the traditional exploitation of open cork oak dehesa (open woodland), has been controversial for long time, both in theory and in practical application. However the available information is insufficient to form an objective and rational opinion on this important silvicultural and economic practice.

Some experiments were carried out in Portugal, designed to determine the effects of pruning on cork growth, yield and acorn production; and the results were published by
Natividade [11-14] and Santos and Rodrigues [17]. The only experimental work in this field in Spain has been that of Montero and Curras [10], designed to quantify firewood and virgin cork obtained by moderate pruning.

The so-called formation pruning, to rectify deformed trunks or branch distribution in the young tree, is highly valuable in the long term. It increases the yield and enhances cork quality by reducing the cork wastes and extraction costs.

The pruning of adults trees originates from the emulation of holm oak (Quercus ilex subp. ballota) pruning, which

* Correspondence and reprints

Tel.: 3491 3476867; fax: 3491 3572293; e-mail: canellas@inia.es 
results in more regular and sustainable acorn production, and reduction in crown cover favouring cereal crops and the supply of grazing for cattle.

Light or moderate pruning is good for the tree, in general, ridding it of overshadowed or weak branches with a negative energy balance, and for increasing the acorn yield. This is particularly true on nutrient-poor soils and where there is a summer water supply deficiency. This type of pruning does not reduce diameter growth, and may even slightly increase it at times $[7,8]$.

The economic costs of light or moderate pruning are, however, very high. As a result, attempts to compensate for this by incoming from firewood, charcoal or virgin cork, lead to increase the intensity of pruning. Thus, pruning is usually very intensive or even excessive. This in turn means that pruning may have to be carried out more often, in order to correct imbalances in the crown.

Another drawback of intense pruning is that it is followed by periods of little or no fruit production, since allocation is made to crown restoration and reduce the imbalance between aerial and root biomass, usually by means of sucker sprouts or epicormic shoots. Such excessive pruning is not justified from the point of view of fruit production, since it reduces the productive surface. Although there may be abundant acorns on the few remaining branches, this has not been shown to result in increased overall production. Moreover, the remaining crown surface available for photosynthetic activity may be so reduced as to lead to a serious slowing of diameter growth [7].

However the lack of knowledge about the effect of silvicultural practices (e.g. pruning thinning, debarking levels) that are usually applied in cork oak stand management, on tree and cork growth, make difficult the develop and validate growth and yield models for cork oak stands [16].

For these reasons, we set up experiments with the aim of quantifying the effect of pruning on cork yield. This was done by comparing pruned with unpruned trees in relation to cork yield per tree, production of cork for each square metre stripped, and annual cork growth. Other aspects of physiological nature were not taken into consideration.

\section{MATERIALS AND METHODS}

\subsection{Description of experimental sites}

This work was carried out in two ways: synchronically, comparing pruned sites with others which were either unpruned or pruned at a different time, and diachronically, where pruning was performed in the middle of the cork-cropping cycle within a group of trees, comparing these with others which had not been pruned.

\subsubsection{Synchronic study: characteristics of the sample}

The choice of sites was made after a complete examination of the cork oak dehesas of Cáceres province. The advantage of this type of woodland was that it allowed sites to be selected in which there had been pruning in previous years, thus allowing us to measure the responses of the tree to treatment without having to carry out the treatment first and then wait for a whole cork-cropping cycle to pass. It also allowed us to quantify the effects of pruning carried out many years before. One disadvantage is that we do not have information or proper estimates assessing the intensity of pruning.

In each plot, trees were selected to cover the whole of the existing diameter range, and so that the treatments (pruned/unpruned trees, or those with different pruning dates) could be represented by paired data, with trees of the same or very similar circumference over cork (COC), and similar stripping height of trunk ( $\mathrm{SH})$. The paired trees were very close together, and had the same ecological and silvicultural characteristics, with the exception of pruning treatment. The sites (figure 1) are described as follows:

“La Herguiijuela": Located in $39^{\circ} 51^{\prime}$ N, 5' 55' W, UTM: $30 \mathrm{~S}$ TK01. In 1994 a sample of 22 trees pruned in the winter of 1990 and another 22 trees, which had not been pruned for at least twenty years were selected. Cork stripping was carried out in June 1994, after a rotation cycle of eleven years.

Valcorchero wood, zone 1: Located in $40^{\circ} 05^{\prime} \mathrm{N}, 6^{\circ} 10^{\prime} \mathrm{W}$, UTM: 29S QE53. In October 1992 a sample of 20 trees pruned in the winter of 1989, four years before stripping, and another 20 trees pruned in 1980 (during the previous cork-production cycle) were selected. The cork stripping was carried out in July 1994, after a 10year cycle.

Valcorchero wood, zone 2: Located in $40^{\circ} 05^{\prime} \mathrm{N}, 6^{\circ} 10^{\prime} \mathrm{W}$, UTM: 29S QE53. In October 1992 a sample of 20 trees pruned in the winter of 1991 and another 20 trees not pruned (for at least twenty years) were selected. Cork stripping was carried out in June 1995, after a 10-year cycle.

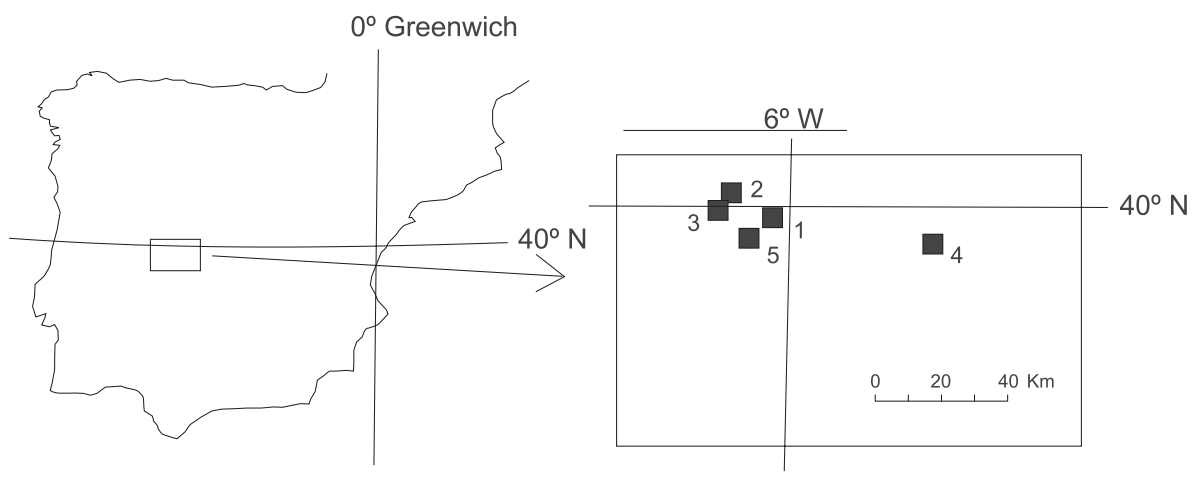

Figure 1. Location of experimental sites in Extremadura region (Spain). 
The climate is continental Mediterranean and the potential vegetation is that of the Sanguisorbo agrimonioidis-Quercetum suberis [15] type of cork oak forest in all of the sites.

The two sub-sections of each site were laid out together, so that the trees inside them were as similar as possible in size, appearance, silvicultural characteristics and state of health. In this way, any differences in yield could be attributed mainly to the pruning treatment carried out. The intention, then was to compare trees pruned three or four years before stripping with others pruned 13-14 years before (i.e. during the previous cycle), or not pruned for at least twenty years.

\subsubsection{Diachronic study: characteristics of the sample}

In order to maintain a rigorous control over the treatment, pruning was carried out in two test areas. This was performed by staff used to this kind of silvicultural treatment, but advised and checked by ourselves. Thus the intensity of pruning on all trees was similar, and was evaluated at the same time.

“El Dehesón del Encinar" estate: Located in 39 50' N, $5^{\circ} 05^{\prime} \mathrm{W}$, UTM: 30S UK23. Pruning was carried out in December 1993 on 40 trees, and these were compared with 40 others left unpruned. Cork stripping took place in August 1998, at the end of a ten-year cycle.

'Las Cansinas del Oeste" estate: Located in $39^{\circ} 58^{\prime} \mathrm{N}, 6^{\circ} \mathrm{W}$, UTM 30S TK51. Pruning was carried out in December 1993 on 40 trees, and these were compared with 40 others left unpruned. Cork stripping was in June 1998, after a 9-year cycle.

Both sites have a continental Mediterranean climate and the potential vegetation of the area where data was gathered is that of Sanguisorbo agrimonioidis-Quercetum suberis type of cork oak forest according to Rivas Martínez [15]

The trees were selected in pairs according to their circumference over cork at breast height, covering all the diameter classes present in the area. One of the samples consisted of 40 trees which were not going to be pruned, and the other of 40 trees which were pruned four years after stripping.

The pruning consisted mainly of eliminating low branches wherever possible, reducing crown diameter, leaving some branches in the middle of the crown which would overshadow first-order branches and assure a round-shaped crown. Particular attention was paid to avoid rot, by not leaving horizontal cut surfaces liable to accumulate of rainwater. Attention was also paid to maintain crown balance and branches above $20 \mathrm{~cm}$ base diameter were not cut. The remaining branches were cleaned of dry or withered twigs [10].

It is difficult to quantify the intensity of pruning, since this depends on the initial number of branches and the number of branches cut off. Effort was made not to cut more than $30 \%$ of crown volume, only exceeding this limit where the shape of tree or crown made it advisable for the future growth of the tree. A rule maintained by specialists is that the ideal intensity of pruning is that where the tree does not respond by throwing out suckers, or at least only very few. In the two sites only $8 \%$ and $10 \%$ of the trees sprouted relatively profusely, indicating that they had been pruned more heavily. It can thus be deduced that pruning was of moderate to strong intensity.

The pruning intensity was estimated considered the biomass cut off in relation with the circumference over cork by tree according with Montero and Curras [10].

\subsection{Data gathering}

In each plot the trees were individually identified and numbered, and the following data measured:

- Breast height circumference over cork (COC) and under cork (CUC) to the nearest centimetre.

- Base circumference (BC), mid-point (MC) and the top (TC) of the trunk in centimetres.

- Height of cork stripping in trunk (SH), to the nearest centimetre.

- Mean circumference $\left(\mathrm{BC}_{\mathrm{i}}\right)$ and stripped length $\left(\mathrm{BL}_{\mathrm{i}}\right)$ of each stripped branch.

- Total cork weight (green matter), immediately after stripping, to the nearest $25 \mathrm{~g}$.

- Mean thickness of cork for each tree, calculated by averaging the thickness of three cork planks selected at random immediately after being removed from the tree, and the thickness measured at two mid-points of each plank.

- Two pieces of cork measuring about $20 \times 20 \mathrm{~cm}$ were random collected from each tree and taken to the laboratory. A thin slice was cut, one of its faces was sanded, and a microscope was used to measure annual cork growth.

- Biomass cut off during pruning was weighed (in $\mathrm{kg}$ ) for each pruned tree in the El Dehesón del Encinar site (40 trees), and in an additional sample of 27 trees selected so as to include all the diameter classes present in the Las Cansinas site. Samples of biomass were taken in order to estimate the humidity (oven-dried at $105^{\circ} \mathrm{C}$ till constant weight). Later the biomass was sorted into two groups: firewood (branches over $5 \mathrm{~cm}$ in diameter, with virgin cork) and brushwood (branches under $5 \mathrm{~cm}$ in diameter with leaves).

On the basis of the variables measured in the field, other variables were defined, characterising the tree as a producer of cork:

- Surface stripped from the trunk (SST), from branches (SSB) and in total (SS).

- Weight of cork per square metre of stripped surface (WCSM) in $\mathrm{kg} \mathrm{m}^{-2}$.

- Mean thickness of cork (MTC), in mm.

- Coefficient of stripping (CS): quotient of the maximum length of cork stripping and the beast height circumference over cork.

- Intensity of stripping (IS): quotient of the total stripped area (SS) and the sectional area under cork at $1.30 \mathrm{~m}$ (CUC):

$$
\mathrm{IS}=\frac{\mathrm{SS}}{\mathrm{CUC}^{2} / 4 \cdot \pi} .
$$

The stripping height on trunk and branches was maintained and therefore no virgin cork was obtained from stripped trees.

\subsection{Statistical treatment}

Treatments were examined for statistically significant differences. Variance analysis was carried out, taking the data as a design of completely random blocks for each of the variables under consideration. Paired comparisons were also made, using the t-test.

In order to estimate the biomass removed, the variable most closely correlated with weight was selected, and linearized allometric equations were adjusted by Napierian logarithms. 


\section{RESULTS}

\subsection{Pruning quantification for Las Cansinas and El Dehesón}

Average figures for biomass obtained from pruning in the plots in El Dehesón del Encinar and Las Cansinas are shown in table I. Depending on the circumference classes, the biomass obtained from pruning ranged from $45-63$ to $1440-1160 \mathrm{~kg} \mathrm{tree}^{-1}$ in green matter for Deheson and Cansinas, respectively.

In the sample, the firewood had 36-38\% humidity and the brushwood $39-41 \%$ (57-61\% in leaves and $38-40 \%$ in brushwood without leaves) in the El Dehesón and Las Cansinas sites respectively. Biomass increased with tree dimensions as shown in figure 2. Table II shows the allometric relations found in the sample.

There are statistically significant relationships between the total biomass, firewood and brushwood and the breast height circumference over cork. The adjusted models explain $66-78 \%$ of the variability of the variables, and can therefore be considered acceptable.

Table I. Biomass obtained from pruning ( $\mathrm{kg} /$ tree, green matter) in El Dehesón del Encinar (40 trees) and Las Cansinas (27 trees).

\begin{tabular}{llcccc}
\hline & & $\begin{array}{c}\text { Circumfe- } \\
\text { rence over } \\
\text { cork, cm }\end{array}$ & \multicolumn{3}{c}{ Biomass, kg/tree } \\
\cline { 3 - 6 } & Firewood & Brushwood & Total \\
\hline \multirow{3}{*}{ Dehesón } & 130 & 316 & 167 & 483 \\
& Maximum & 212 & 1013 & 427 & 1440 \\
& Minimum & 76 & 25 & 20 & 45 \\
& Stand. deviation & 29 & 203 & 82 & 276 \\
\cline { 5 - 6 } Cansinas & Mean & 140 & 295 & 176 & 471 \\
& Maximum & 190 & 879 & 407 & 1160 \\
& Minimum & 95 & 30 & 34 & 63 \\
& Stand. deviation & 26 & 205 & 89 & 284 \\
\hline
\end{tabular}

Table II. Allometric relations between estimates of total biomass and the firewood and brushwood biomass ( $\mathrm{kg} / \mathrm{tree}$, green matter) obtained from pruning in the Dehesón del Encinar and the Las Cansinas plots. The following linear model was used: $\operatorname{Ln}(\mathrm{Y})=\operatorname{Ln}(\mathrm{a})+\mathrm{b} \times$ $\mathrm{Ln}(\mathrm{COC})$

\begin{tabular}{|c|c|c|c|c|c|c|c|}
\hline Sites & Y & n(a) & $\mathbf{S}(\operatorname{Ln}(\mathbf{a}))$ & b & (b) & $\mathbf{R}^{2}$ & $P$ value \\
\hline \multirow{3}{*}{ Dehesón } & Diona & & & & & 6 & \\
\hline & ${ }^{1}$ Firewood & & & & & 1 & \\
\hline & wood & & & & & & \\
\hline \multirow{3}{*}{ Cansinas } & 1 & & & & & 77.64 & 0.0000 \\
\hline & Firewood & & & & & 1 & .0000 \\
\hline & Brushwood & -7.8493 & 1.7355 & 2.6157 & 0.3523 & 68.79 & 0.0000 \\
\hline
\end{tabular}

a and b: adjustment parameters; S(a), S(b): standard error of the estimate; COC: circumference over cork.

\subsection{Influence of pruning on cork yield}

Table III presents information concerning the size of the trees studied. Mean values for the plot are given, and, in order to provide more detail about the sample analysed, the standard mean deviation, and the maximum and minimum values for circumference over cork.

The results per site (table III) showed a high variability in most of parameters considered. The coefficient of variation of the mean rate was $20 \%$ in most cases.

Table IV gives information concerning variables characterizing the tree as a cork producer, such as the height to which the trunk is stripped, the total length of stripping, the surface area stripped, and the indices and coefficients of stripping which reveal the intensity of stripping.

The stripping coefficient (CS) is always under 2.6 in all sites (table IV). Thus, the trees are not excessively stripped; if this was not the case the objective of the study would be affected. However a tree stripped only on the trunk may have the same coefficient as one stripped on both trunk and branches, but has to withstand a much lower pressure of stripping than the latter. In fact, when over a third of the surface area stripped is on the branches, it is recommended not to exceed a value of 2.5 for the cork stripping coefficient [9].

The stripping index (IS) is a better indicator of stripping pressure on a tree. In all the test sites except that of Las Cansinas, the IS was between 29 and 33, lower than the values recommended by Montero [9], who refers that a cork harvest can be obtained in a rational manner with stripping intensity values of less than 34-36. In the case of Las Cansinas, where most trees have been stripped on both trunk and branches, the stripping index is higher (45). We should to bear in mind that the stripping index is expressed by the coefficient between the surface area stripped and the area of the breast height section of the tree $(1.30 \mathrm{~m})$.

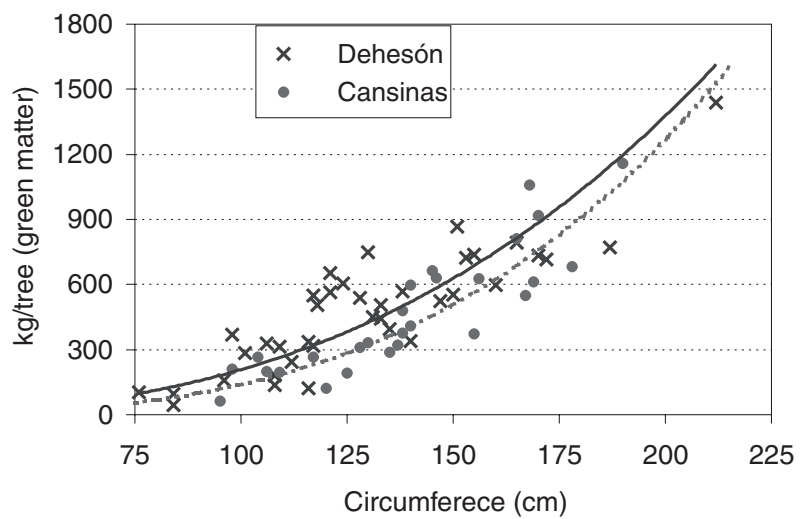

Figure 2. Total biomass ( $\mathrm{kg} / \mathrm{tree}$, green matter) obtained from pruning in relation to normal circumference over cork for the plots in El Dehesón and Las Cansinas. 
Table III. Main silvicultural characteristics of the experimental sites.

\begin{tabular}{|c|c|c|c|c|c|c|c|c|c|c|c|c|c|}
\hline \multirow{2}{*}{ Plots } & \multirow{2}{*}{ Treatments } & \multicolumn{4}{|c|}{$\mathrm{COC}$} & \multicolumn{2}{|c|}{ CUC } & \multicolumn{2}{|c|}{ TC } & \multicolumn{2}{|c|}{ MC } & \multicolumn{2}{|c|}{ BC } \\
\hline & & mean & s.d. & $\max$. & $\min$. & mean & s.d. & mean & s.d. & mean & s.d. & mean & s.d. \\
\hline \multirow{2}{*}{ La Herguijuela } & pruning 1990 & 150 & 23 & 204 & 110 & 133 & 21 & 131 & 30 & 135 & 23 & 154 & 24 \\
\hline & no pruning & 150 & 23 & 207 & 109 & 131 & 20 & 126 & 25 & 133 & 20 & 156 & 25 \\
\hline \multirow{2}{*}{ Valcorchero 1} & pruning 1980 & 187 & 27 & 247 & 136 & 168 & 27 & 183 & 31 & 168 & 26 & 190 & 32 \\
\hline & pruning 1989 & 190 & 27 & 240 & 134 & 172 & 26 & 182 & 36 & 172 & 26 & 196 & 31 \\
\hline \multirow{2}{*}{ Valcorchero 2} & pruning 1992 & 142 & 31 & 220 & 98 & 125 & 31 & 127 & 38 & 126 & 30 & 141 & 32 \\
\hline & no pruning & 147 & 35 & 230 & 100 & 129 & 34 & 132 & 38 & 131 & 35 & 149 & 38 \\
\hline \multirow{2}{*}{ Dehesón } & pruning 1993 & 134 & 30 & 219 & 84 & 120 & 29 & 126 & 34 & 122 & 34 & 147 & 41 \\
\hline & no pruning & 141 & 29 & 201 & 84 & 125 & 28 & 135 & 37 & 127 & 34 & 157 & 37 \\
\hline \multirow{2}{*}{ Cansinas } & pruning 1993 & 136 & 25 & 190 & 90 & 122 & 24 & 140 & 28 & 122 & 23 & 156 & 30 \\
\hline & no pruning & 138 & 27 & 215 & 95 & 124 & 25 & 142 & 32 & 125 & 26 & 152 & 31 \\
\hline
\end{tabular}

COC: circumference over cork at $1.30 \mathrm{~cm}(\mathrm{~cm})$; CUC: circumference under cork at $1.30 \mathrm{~m}$ (cm); TC: circumference at the top of the trunk under cork $(\mathrm{cm})$; MC: circumference at mid-point of the trunk under cork $(\mathrm{cm})$; BC: circumference at the base of the trunk under cork (cm); s.d.: standard mean deviation; max.: maximum value; min.: minimum value.

Table IV. Variation in stripped height, stripped surface and intensity of stripping in the experimental plots.

\begin{tabular}{|c|c|c|c|c|c|c|c|c|c|c|c|c|c|c|c|}
\hline \multirow[t]{2}{*}{ Plots } & \multirow[t]{2}{*}{ Treatment } & \multicolumn{2}{|c|}{ SH } & \multicolumn{2}{|c|}{ LS } & \multicolumn{2}{|c|}{ SS } & \multicolumn{2}{|c|}{ SST } & \multicolumn{2}{|c|}{ SSB } & \multicolumn{2}{|c|}{ IS } & \multicolumn{2}{|c|}{ CS } \\
\hline & & mean & s.d. & mean & s.d. & mean & des. & mean & s.d. & mean & s.d. & mean & s.d. & mean & s.d. \\
\hline \multirow{2}{*}{ La Herguijuela } & pruning 1990 & 255 & 47 & 285 & 64 & 4.19 & 1.57 & 3.59 & 0.97 & 0.6 & 1.04 & 29.24 & 6.66 & 1.92 & 0.44 \\
\hline & no pruning & 270 & 62 & 293 & 95 & 4.32 & 2.27 & 3.80 & 1.31 & 0.52 & 1.14 & 30.23 & 7.60 & 1.95 & 0.44 \\
\hline \multirow{2}{*}{ Valcorchero 1} & pruning 1980 & 230 & 32 & 356 & 93 & 7.82 & 3.97 & 4.15 & 0.97 & 3.67 & 3.23 & 33.34 & 10.74 & 1.89 & 0.35 \\
\hline & pruning 1989 & 256 & 54 & 338 & 112 & 7.47 & 3.97 & 4.70 & 1.40 & 2.77 & 2.89 & 29.99 & 9.83 & 1.77 & 0.48 \\
\hline \multirow{2}{*}{ Valcorchero 2} & prunng 1992 & 245 & 40 & 279 & 71 & 4.03 & 2.15 & 3.27 & 1.18 & 0.76 & 1.18 & 31.51 & 6.81 & 2.00 & 0.40 \\
\hline & no pruning & 242 & 53 & 272 & 74 & 4.14 & 2.28 & 3.46 & 1.54 & 0.68 & 1.01 & 30.05 & 7.41 & 1.86 & 0.32 \\
\hline \multirow{2}{*}{ Dehesón } & pruning 1993 & 247 & 68 & 283 & 82 & 4.03 & 2.24 & 3.30 & 1.46 & 0.73 & 1.20 & 33.53 & 8.06 & 2.10 & 0.50 \\
\hline & no pruning & 264 & 95 & 307 & 104 & 4.53 & 2.21 & 3.75 & 1.77 & 0.78 & 0.94 & 35.00 & 8.59 & 2.22 & 0.51 \\
\hline \multirow{2}{*}{ Cansinas } & pruning 1993 & 230 & 53 & 352 & 73 & 5.73 & 2.11 & 3.26 & 1.07 & 2.47 & 1.51 & 46.84 & 6.79 & 2.60 & 0.32 \\
\hline & no pruning & 237 & 54 & 337 & 70 & 5.47 & 2.17 & 3.37 & 1.24 & 2.10 & 1.34 & 43.70 & 7.14 & 2.41 & 0.52 \\
\hline
\end{tabular}

SH: height stripped in trunk (cm); LS: length stripped in trunk and branches (cm); SS: surface stripped (m²); SST: trunk surface stripped (m²); SSB: branch surface stripped $\left(\mathrm{m}^{2}\right)$; IS: intensity of stripping; CS: stripping coefficient; s.d.: standard mean deviation.

In order to prove that there were no statistical differences between the trees in each site, the paired data comparison test was applied so as to analyse possible differences between those variables measured directly in the field (COC, CUC, $\mathrm{BC}, \mathrm{MC}, \mathrm{TC}, \mathrm{SH}$ and LS) and those worked out from the previous variables (SS, SST, SSB, IS and CS). This allows to as certain that the sample analysed was homogeneous, and that any differences in cork yield, would not be due to initial differences in the silvicultural conditions.

There were no significant differences (t-test analysis for paired samples) for most of the variables, which seems to indicate that the silvicultural characteristics (tree size and intensity of cork stripping) of the paired trees are similar. In Las Cansinas there were differences in total stripping length, and thus in the indices measuring stripping intensity. These differences will need to be taken into account later when evaluating cork yield and thickness.

Table $V$ gives mean values for the cork yield per tree and per square metre of stripped surface, and the cork thickness for each site and treatment. It can be seen that Valcorchero (zone 1) has the highest mean yield values $\left(>70 \mathrm{~kg}\right.$ tree $\left.^{-1}\right)$, while Dehesón del Encinar shows the highest values of cork weight per square metre stripped and of cork thickness. In
Las Cansinas, the higher stripping intensity did not appear to have any negative influence on the mean cork production parameters. The mean productivity was $9.74 \mathrm{~kg} \mathrm{~m}^{-2}$. Similar values have reported by other authors [6, 14].

Table VI gives the results of the paired data comparison test for the five sites. No significant differences were found for any of the three production variables: mean yield per tree, kilograms per square metre of surface area stripped, and cork thickness.

The differences, with regard to stripping length and the indices of stripping intensity, between pruned and unpruned trees in Las Cansinas, did not result in differences in the variables quantifying cork yield.

\subsection{Influence of pruning on growth and thickness of cork}

The cork growth rings for the two samples taken from each tree at the time of stripping were measured, and an arithmetic mean was calculated later. The results obtained for each site and treatment are shown in figures 3, 4, 5, 6 and 7.

In the five figures only the whole cork growth years have been represented. Thus for nine-year rotations there will be 
Table V. Variation in cork yield ( $\mathrm{kg}$ tree $^{-1}$ and $\mathrm{kg} \mathrm{m}^{-2}$ of stripped surface) and thickness $(\mathrm{mm})$ in the experimental sites.

\begin{tabular}{|c|c|c|c|c|c|c|c|c|}
\hline \multirow[t]{2}{*}{ Sites } & \multirow[t]{2}{*}{ Treatment } & \multirow{2}{*}{$\begin{array}{c}\text { Year } \\
\text { of stripping }\end{array}$} & \multicolumn{2}{|c|}{ Mean yield } & \multicolumn{2}{|c|}{ WCSM } & \multicolumn{2}{|c|}{ thickness } \\
\hline & & & mean & s.d. & mean & s.d. & mean & s.d. \\
\hline La Hergüijuela & pruning 1990 & 1994 & 36.38 & 14.21 & 8.78 & 2.01 & 28.33 & 5.13 \\
\hline \multirow{2}{*}{ Valcorchero 1} & pruning 1980 & \multirow{2}{*}{1994} & 75.31 & 41.82 & 9.54 & 1.54 & 32.06 & 4.16 \\
\hline & pruning 1989 & & 71.83 & 34.14 & 10.22 & 3.06 & 32.97 & 6.35 \\
\hline Valcorchero 2 & pruning 1992 & 1995 & 33.33 & 18.81 & 8.22 & 1.31 & 26.55 & 3.92 \\
\hline \multirow{2}{*}{ Dehesón } & pruning 1993 & \multirow{2}{*}{1998} & 45.68 & 27.00 & 11.30 & 2.22 & 33.29 & 5.92 \\
\hline & no pruning & & 51.54 & 25.69 & 11.51 & 2.18 & 35.02 & 5.68 \\
\hline \multirow[b]{2}{*}{ Cansinas } & pruning 1993 & \multirow{2}{*}{1998} & 59.02 & 34.25 & 9.90 & 2.46 & 28.82 & 5.75 \\
\hline & no pruning & & 55.06 & 30.60 & 9.68 & 2.14 & 30.32 & 6.47 \\
\hline
\end{tabular}

Mean yield: $\mathrm{kg}$ tree ${ }^{-1}$; WCSM: $\mathrm{kg}$ of cork per $\mathrm{m}^{2}$ of stripped surface; s.d.: standard mean deviation; Thickness: mm.

Table VI. t-test analysis for paired samples, confidence interval 95\%, for each of the product variables defined.

\begin{tabular}{llccc}
\hline \multicolumn{1}{c}{ Sites } & \multicolumn{1}{c}{ Treatment } & Mean yield & WCSM & Thickness \\
\hline La Hergüijuela & pruning 1990/NP & n.s. & n.s. & n.s. \\
Valcorchero 1 & pruning 1980/89 & n.s. & n.s. & n.s. \\
Valcorchero 2 & pruning 1992/NP & n.s. & n.s. & n.s. \\
Dehesón & pruning 1993/NP & n.s. & n.s. & n.s. \\
Cansinas & pruning 1993/NP & n.s. & n.s. & n.s. \\
\hline
\end{tabular}

Mean yield: $\mathrm{kg}$ tree ${ }^{-1}$; WCSM: $\mathrm{kg}$ of cork per $\mathrm{m}^{2}$ of stripped surface; n.s.: no significant differences at $95 \%$ confidence level; NP: no pruning.

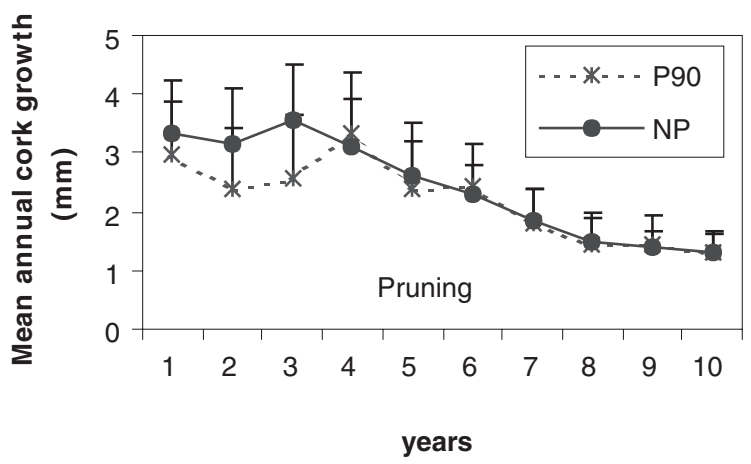

Figure 3. Cork growth rings in the La Hergüijuela test site. Year of stripping 1994, 11-year rotation, pruning in 1990. NP denotes no pruning trees for at least twenty years. P90 denotes pruned trees during the winters of 1990.

8 whole mean annual growths, and approximately two halfyears, corresponding to the first autumn following stripping and the last spring before a final stripping. Similarly, for tenand eleven-year rotations.

The annual cork growth the year after stripping was not the greatest in opposite the results reported by Ferreira et al. [4]. In our case, the greatest cork growth was obtained the second or third year after stripping.

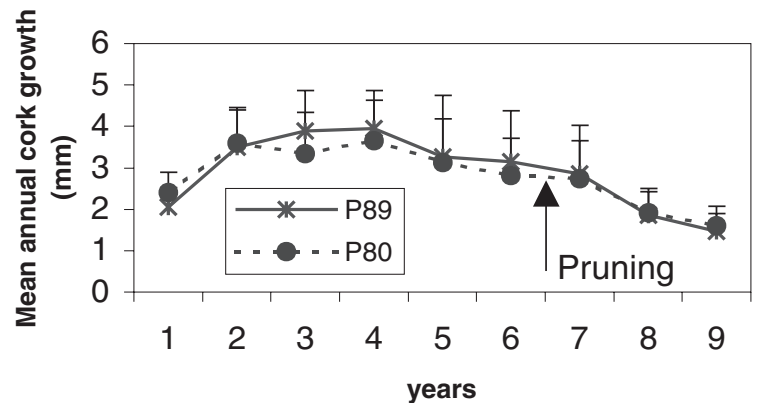

Figure 4. Cork growth rings in the Valcorchero zone 1 test site. Year of stripping 1994, 10-year rotation, time since the last pruning 14 and 4 years respectively. P80 and P89 denote pruned trees during the winters of 1980 and 1989 respectively.

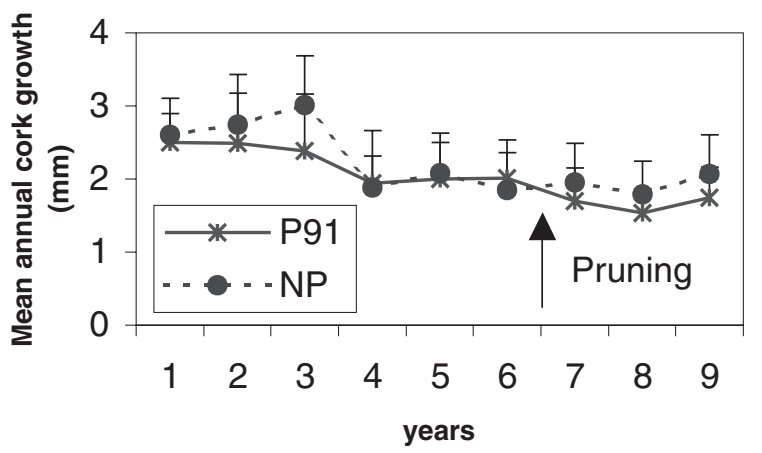

Figure 5. Cork growth rings in the Valcorchero zone 2 test site. Year of stripping 1995, 10-year rotation, time since the last pruning, in 1991, 4 years. NP denotes no pruning trees for at least twenty years. P91 denotes pruned trees during the winters of 1991.

A high annual cork growth variability was observed in all sites. This high variability could be explained through the preponderant effect of the tree like source of variation [4]. 


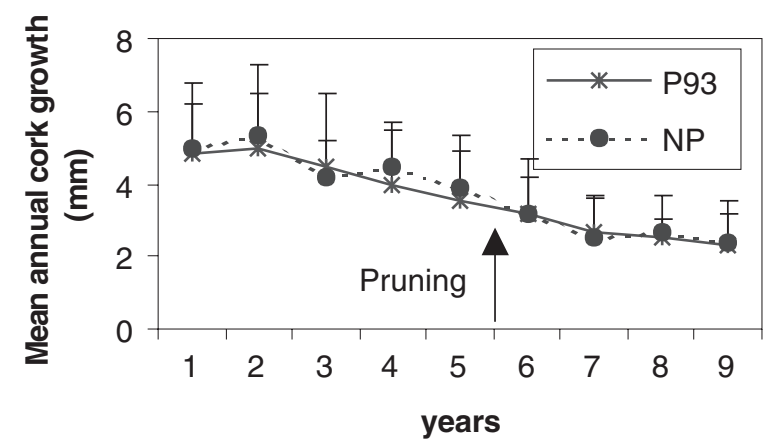

Figure 6. Cork growth rings in the El Dehesón del Encinar test site. Year of stripping 1998, 10-year rotation. Pruning winter in 1993. NP denotes no pruning trees for at least twenty years. P93 denotes pruned trees during the winters of 1993.

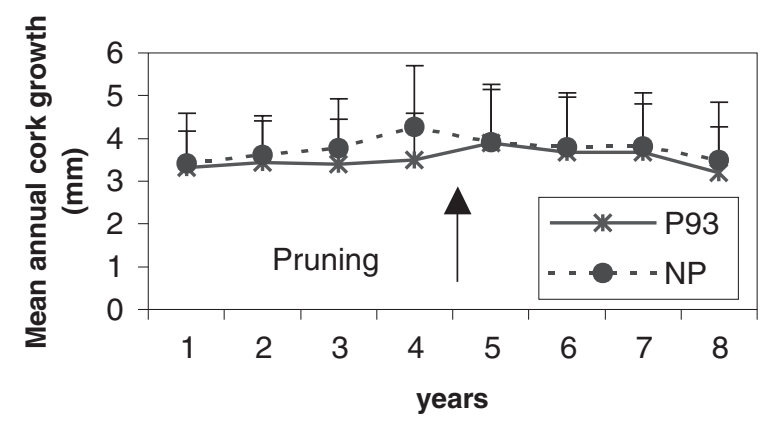

Figure 7. Cork growth rings on the Las Cansinas test site. Stripping in 1998. 9-year rotation. Pruning winter in 1993. NP denotes no pruning trees for at least twenty years. P93 denotes pruned trees during the winters of 1993.

In order to analyse the differences between growth rings the paired data comparison test was applied to the five test sites. There were no cases of significant difference in the cork annual year growth for the year of pruning, nor in the following years when compared with the unpruned trees.

In the years previous to the pruned, some differences were to find in the cork annual growth of the two groups of trees: in the Hergüijuela site in 1986 and 1987, and Las Cansinas sites for 1993.

Cork growth differences before and after pruning were analysed in every tree. No significant differences between pruned and unpruned trees were found for each experimental site.

\section{DISCUSSION}

As we have mentioned, our methods were designed to ensure that pruning did not exceed $30 \%$ of total crown biomass, and at first sight this seemed to be the case. However, when comparing the data for biomass extracted and for circumference over cork (table I) with those published by Montero and Curras [10] for the Cáceres area (for circumference classes between $130-140 \mathrm{~cm}$ the biomass obtained from moderate pruning was $2103 \mathrm{~kg}^{-1} \mathrm{e}^{-1}$ in green matter of firewood and $130 \mathrm{~kg}$ tree $^{-1}$ in green matter of brushwood), it appears that at times almost $40 \%$ of total crown biomass was pruned. It can be concluded that the pruning figures obtained in these two sites are considerably higher than those presented by the latter authors, for two main reasons: the pruning carried out in the Montero and Curras [10] study was relatively moderate, while in the present study the trees in the sample had not been pruned for a long time, and had abundant woody biomass in the crown. As we remarked in the Methods section, frequency of pruning is a determining factor in its intensity.

The equations obtained for estimating the woody biomass pruned conform with the methodology usually employed in these studies [1-3,5], and fit the measured data well in all the fractions analysed. Although the data were not sorted according to units of surface area, the equations derived from tree diameters would allow to estimate fairly accurate woody biomass pruned in a dehesa of a certain density and mean tree size.

This model could be considered like an approach to estimate de firewood with pruning in cork oak woodlands. Although the model only included like independed variable the breast height circumference, we have to take in account the height of these trees (pruning every 15-20 years) do not improve, normally, the adjustment.

There is not much data from earlier studies on the effect on pruning on cork yield with which to compare the results obtained from this study.

According to Natividade [13] the benefits obtained from rational pruning, carried out with biological rather than productivity-oriented aims, are indisputable; it creates better conditions for the cork-generating layer, rejuvenates the branch system, and increases growth rate and cork yield. Our results do not appear to confirm this, since neither the mean cork yield per tree, nor per square metre stripped, nor cork thickness seem to be affected by pruning. We may even consider the hypothesis that pruning, even of moderate intensity, results in an imbalance between the aerial and root biomass which, in turn, diverts energy to leaf production at the expense of cork yield.

From the point of view of cork yield, Natividade [11, 12] showed that an excessively pruned cork oak forest yields $20 \%$ less cork than others with similar characteristics (age, and silvicultural and ecological conditions) which had been moderately pruned, as a results from a diameter growth decrease of $20 \%$ in the excessively pruned plot.

We did not find this reduction in cork production immediately after pruning, presumably because pruning was not excessive on any of the trees in the five test sites. But neither we 
did note an increase in cork yield, as did Natividade [13], when pruning was not excessive.

In our experiment the effect of pruning on cork thickness was measured in the immediately following years in four test sites, and the possible longer-term effects of pruning carried out before the current cork rotation period were measured in one test site.

In Valcorchero, zone 1, (figure 4) the effects of pruning carried out four years before stripping (P89) were compared with that carried out fourteen years before stripping (P80). The results showed no significant differences in cork growth.

In Valcorchero, zone 2, (figure 5) and La Hergüijuela (figure 3) unpruned trees, or those pruned over twenty years before (NP) were compared with those pruned four years before the last stripping. This case, too, failed to reveal statistically significant differences in cork yield or yearly growth.

In the Las Cansinas (figure 7) and El Dehesón (figure 6) test sites, trees pruned four years before stripping were compared with unpruned trees. Results in these two sites can be regarded as duplicating those in Valcorchero, zone 2, and in La Hergüijuela, though the additional information obtained about pruning intensity enables us to draw conclusions with greater confidence. In these cases, too, failed to reveal statistically significant differences in cork yield or yearly growth.

The varied nature of the test situations in this experiment cover a fairly wide range of the possible situations related to pruning in a cork oak forest. This, together with the ecological and silvicultural variability of the cork oak forests in which the experiments were carried out, permit us to assign a high degree of reliability to the results.

These results mean that we do not have to take common silvicultural practices like pruning into account when developing of growth and yield models cork production in cork oak stands. The effects in wood growth are not known until now.

Other effects produced by pruning damage, such as infection by fungi or insects, rotting, torn branches or physiological problems have not been measured in this experiment.

\section{CONCLUSIONS}

Pruning of strong (but not excessive) intensity does not significantly influence the quantity of cork produced by a tree, nor the cork produced per square metre of the stripped surface area, nor the thickness of annual growth produced after pruning. These results mean that we do not have to take common silvicultural practices like pruning into account when developing of growth and yield models cork production in cork oak stands.
Other effects produced by pruning damage, such as infection by fungi or insects, rotting, torn branches or physiological problems have not been measured in this experiment.

Acknowledgements: Our thanks go to all the owners of the sites, the Forest Service of the province of Cáceres for allowing us to record data, and all those involved in the collection of field and laboratory data, particularly A. Bachiller, M ${ }^{\mathrm{a}}$ A. Suarez and E. Torres. The authors also thank C. Farrel for the paper translation.

\section{REFERENCES}

[1] Cañellas I., San Miguel A., Del Río V., Evaluación de la producción silvopastoral de una dehesa extremeña: pasto, bellota y biomasa de ramas podadas, XXXI Reunión Científica de la SEEP, Murcia, in: Congresos 4, Consejería de Agricultura, Ganadería y Pesca de la Región de Murcia, 1989, pp. 234-240.

[2] Cañellas I., San Miguel A., Biomass of root and shoot systems of Quercus coccifera shrublands in Easter Spain, Ann. For. Sci. 57 (2000) 803-810.

[3] Elk A.R., A model for estimating branch weight and branch leaf weight in biomass studies, For. Sci. 25 (1979) 303-306.

[4] Ferreira A., Lopes F., Pereira H., Caractérisation de la croissance et de la qualité du liège dans une région de production, Ann. For. Sci. 57 (2000) $187-193$.

[5] Gomez A.G., Tovar J.J., Medina M., Martinez A., Relaciones entre diámetro de tallo y peso de las ramas en cuatro especies leñosas mediterránea, Arch. Zootec., 25 (1986) 149-154.

[6] González Adrados J.R., Montero G., Ortega M., Caracterización productiva de los alcornocales catalanes, Investig. Agrar., Sist. Recur. For. 2 (1993) 55-69.

[7] Hawley R.C., Smith D.M., Silvicultura Práctica, Omega, 1972.

[8] Hubert M., Courrand R., Poda y formación de los árboles forestales, Mundi-Prensa, 1989.

[9] Montero G., Modelos para cuantificar la producción de corcho en alcornocales en función de la calidad de la estación y de los tratamientos selvícolas, Tesis Doctorales, 75 INIA Madrid, 1987.

[10] Montero G., Curras R., La poda del alcornocal (Quercus suber L.). Cuantificación de sus productos, Hojas divulgadoras, MAPA, No 18-19, 1990.

[11] Natividade J., Poda dos sobreiros, Sep. Bol. Min. Agric. XIII (1932) $1-29$.

[12] Natividade J., Técnica cultural dos sobreirais, I Poda, Junta Nacional da Cortiça, Lisboa, 1937.

[13] Natividade J., A propósito da arreira, in: Campanha de Protecçao do sobreiro, I. Poda, Junta Nacional Cortiça, Lisboa, 1947, pp. 13-25.

[14] Natividade J., Subericultura. Dir. Geral dos Ser. Florestais e Aquicolas, Lisboa, (Spanish edition 1992), M.A.P.A., Madrid, 1950.

[15] Rivas Martínez S., Memoria del Mapa de Series de Vegetación de España, ICONA, Madrid, 1986.

[16] Tomé M., Coelho M.B., Pereira H., Lopes F., A management oriented growth and yield model for cork oak stands in Portugal, Empirical and process based models for forest tree and stand growth simulation, Amaro A., Tomé M. (Ed.), 1999, 271-289.

[17] Santos B., Rodrigues F., Do podador de sobreiros e do tirador de cortiça, Instituto dos Produtos Florestais, 1975. 